This is an electronic version of an article published in Gallagher, K., \& Fusco, C. (2006). I.D.ology and the Technologies of Public (School) Space: An ethnographic inquiry into the neo-liberal tactics of social (re)production. Ethnography and Education, 1(3), 301318. Cognition and Instruction is available online at: www.tandfonline.com with http://www.tandfonline.com/openurl?genre=article\&issn=1745$7823 \&$ volume $=1 \&$ issue $=3 \&$ spage $=301$

\title{
I.D.ology and the Technologies of Public (School) Space: An ethnographic inquiry into the neo-liberal tactics of social (re)production
}

Kathleen Gallagher

Caroline Fusco 


\title{
An ethnographic inquiry into the neo-liberal tactics of social (re)production
}

\section{Authors:}

\author{
Kathleen Gallagher, PhD \\ Department of Curriculum, Teaching and Learning \\ OISE/University of Toronto \\ 252 Bloor Street West \\ Toronto, ON \\ M5S 1V6 \\ 416 923-6641, ext. 2015 \\ kgallagher@oise.utoronto.ca \\ (Corresponding Author)
}

Kathleen Gallagher is Associate Professor and Canada Research Chair in Urban School Research in Pedagogy and Policy in the Department of Curriculum, Teaching and Learning at the Ontario Institute for Studies in Education of the University of Toronto (OISE/UT). Dr. Gallagher's book Drama Education in the Lives of Girls: Imagining Possibilities (University of Toronto Press, 2000) received the American Education Research Association's book award for significant contribution to Curriculum Studies in 2001. Her recent edited collection (ed. K. Gallagher and D. Booth) is entitled How Theatre Educates: Convergences and Counterpoints with Artists, Scholars, and Advocates (University of Toronto Press, 2003). Other recent publications include, Gallagher, K. and P. Lortie. (2005) 'How does knowin' my business make you any safer?": Critical Pedagogy in Dangerous Times. The Review of Education, Pedagogy, and Cultural Studies.Volume Volume 27(2): 141-158; Gallagher, K. (2005) The Aesthetics of Representation: Dramatic Texts and Dramatic Engagement. Journal of Aesthetic Education. Volume 39(4); Gallagher, K. and D. Riviere (2004) Pink...with Shades of Grey: Mediating Moments of Diversity in Urban Secondary Classrooms. Westminster Studies in Education Special Issue: Interactive and Inclusive Pedagogy. Volume 27 (2): 127-141; Gallagher, K. (2004). The Art and Politics of Qualitative Research in Drama Education: Creating Culture, Representing 'Reality'. Drama Research. Volume 4 (1): 318; Gallagher, K. (in press 2006) Sexual Fundamentalism and Performances of Masculinity: an ethnographic scene study. International Journal of Gay and Lesbian Issues in Education 4(1).

The work represented in this paper was based on a three-year ethnographic study, titled Drama Education, Youth, and Social Cohesion: (re)constructing identities in urban contexts. The study was funded by the Social Sciences and Humanities Research Council of Canada and carried out in schools in Toronto, Canada and New York City, USA.

\author{
Caroline Fusco, PhD \\ Faculty of Physical Education and Health \\ University of Toronto \\ 55 Harbord Street
}




\section{An ethnographic inquiry into the neo-liberal tactics of social (re)production}

Toronto, ON

M5S 2W6

416 946-7717

c.fusco@,utoronto.ca

Caroline Fusco is Assistant Professor in the Faculty of Physical Education and Health at the University of Toronto. Recent publications include: Fusco, C. (2004) The space that (in)difference makes: (Re)Producing subjectivities in/through abjection - a locker room theoretical case study. In P. Vertinsky \& J. Bale (Eds.), Sites of sport: Space, place, experience. London \& New York: Routledge, 159-176; Fusco, C. (2002) Bent on changing? Imagining postmodern possibilities for locker rooms. Canadian Woman Studies Journal, 21 (3), 12-29; Fusco, C., \& Kirby, K. (2000) Are your kids safe? Media representations of sexual abuse in sport. In S. Scraton \& B. Watson (Eds.), Sport, leisure identities and gendered spaces. Leisure Studies Association, No. 67, 45-73. Current manuscripts in press: Fusco, C. Inscribing healthification: Governance, risk, surveillance and the subjects and spaces of fitness and health. Journal of Health \& Place; Fusco, C. Cultural Landscapes of purification: Sports spaces and discourses of whiteness. Sociology of Sport Journal; Fusco, C. Spatializing the (Im)Proper Subject: The Geographies of Abjection in Sport and Physical Activity Space. Journal of Sport and Social Issues. 
An ethnographic inquiry into the neo-liberal tactics of social (re)production

\begin{abstract}
This paper explores spatial and architectural theory, and particularly a Foucauldian analysis of space, power, and the subject, as a frame within which to examine moves toward security in North American urban schools. We bring into play empirical data from an ethnographic study of New York City and Toronto schools where policies and technologies of record-keeping, identification-verifying, and spatial arrangements are producing altered experiences of subjectivity and the ways in which youth, workers, and researchers experience public (school) space. What is possible to know in ethnographic studies of these new high-security school sites? We argue that notions of 'risk' and 'otherness' in the nation state, and the exploitation of real fears in the wake of real school violence, have permitted a culture of acute surveillance that significantly alters the enterprise of school-based, ethnographic research.
\end{abstract}


I.D.ology and the Technologies of Public (School) Space:

An ethnographic inquiry into the neo-liberal tactics of social (re)production

I.D.ology and the Technologies of Public (School) Space: An ethnographic inquiry

into the neo-liberal tactics of social (re)production

Dear Visitor: You have been given a pass which indicates a specific room number. You are not permitted to be anywhere else in the building. Thank you for your cooperation. Office of Security and Discipline, signed by the Principal and Assistant Principal Security

Foucault prophesied: “A whole history remains to be written of spaces - which would at the same time be the history of powers (both these terms in the plural) - from the great strategies of geo-politics to the little tactics of the habitat, institutional architecture from the classroom to the design of hospitals, passing via economic and political installations. It is surprising how long the problem of space took to emerge as a historico-political problem" (1980, p.149). Space and subjectivity are inextricably linked. Recently in one of our New York schools, as a researcher, I (first author) knew my place straight away. Presented to me by a security guard, the above-cited letter from the 'Office of Discipline and Security' demarcated the particular classroom in which I was permitted to visit and reinforced the off-limit areas of the rest of the school. But schools, of course, are playing their part in a larger system of administrative control and institutional governance. There is a range of public institutions that, like schools, are regulating citizens, containing risk, and governing space, all in the interest of creating 'safer' communities. ${ }^{i}$ One might argue that the real power of ethnographic study lies in its ability to observe and trouble the everyday practices, the ordinary and habitual moments in given cultures. The moments/episodes in dialogue with the theoretical concepts in this paper, therefore, urge a continued, thoughtful consideration of how the 'great strategies 


\section{An ethnographic inquiry into the neo-liberal tactics of social (re)production}

of geo-politics' shape and are shaped by the everyday 'tactics of the habitat', as they currently bear down, in what we argue is an unprecedented way, on the work of ethnographic researchers.

This ethnographic exploration ${ }^{\mathrm{ii}}$ describes how public schools, in a climate of fear and insecurity, are looking to spatial, surveillance and I.D. technologies to make their spaces 'safe'. To examine this trend, the ethnographers' empirical observations and experiences will be presented as critical episodes throughout the text that aim to substantiate and extend the theoretical concerns of the paper. We will use spatial and architectural theory, and particularly a Foucauldian analysis of space, power, and the subject as a frame within which to analyse these moves toward security in North American urban schools. To this end, the paper draws, in particular, on Foucauldian concepts of discipline, panopticism and governmentality, to suggest that contemporary measures of surveillance are part of a longer history in which disciplinary power operates by organizing architectural and public spaces, and fostering self-governance on the part of its subjects. In dialogue with these theoretical ideas, the empirical data point to technologies of record-keeping, identification-verifying, and spatial arrangements that are producing altered experiences of subjectivity for youth, teachers, administrators, and researchers in public school space.

Rather than an examination of ethnographic methodologies, therefore, this paper looks substantively at new configurations of public school space, as seen through the empirical lens of a recent ethnographic study of students' social identities in the context of their drama classrooms in four New York and Toronto schools. We theorize, in particular, two critical episodes taken from the ethnographic fieldnote data. What we 


\section{An ethnographic inquiry into the neo-liberal tactics of social (re)production}

hope to achieve, ultimately, is an ethno- and geo-graphic picture and theoretical analysis

of the kinds of public school spaces that need to be anticipated and negotiated by

researchers of contemporary ethnographic studies of schools and classrooms. What we

suggest is that new systems of surveillance in schools are also altering the research

practices of ethnographers. In our case, what began as a study examining the experiences

of adolescents in urban drama classrooms, in order to develop a theoretical and

empirically grounded account of the dynamic social forces of inclusion and exclusion

experienced by them, inexorably expanded into a broader examination of the forces of

security and governmentality that impact upon students' experiences of the curriculum

and their everyday school lives. Obviously, these heightened security practices calibrate

the kinds of ethnographies that are possible and produce research/the researcher within a

purported culture of ubiquitous risk. This 'culture' has practical implications. In our

inquiry, questions in interviews, for instance, turned towards our shared experiences of

containment and surveillance in the school such that a new set of understandings began to

preoccupy us.

Researcher: Do you think that school safety and security measures are unfair to some/any/all students?

Student: Sometimes school safety pays attention to things that aren't as important and miss what is really going on.

Researcher: If you ran the school, how would you approach the problem of safety?

Student: I'd make sure my security guards were both diverse and not racist.

Post 9/11 and in the wake of local tragedies like the shootings in Columbine High School in Littleton, Colorado (April 20, 1999) and W. R. Myers High School in Taber Alberta (April 28, 1999) schools- as one important public site- have shouldered a barrage of new surveillance and security regimes. As an extension to studies of the geographies 


\section{An ethnographic inquiry into the neo-liberal tactics of social (re)production}

of youth culture and schools (Holt 2003; Fielding 2000; Skelton \& Valentine 1998; Valentine 2000; Lesko 2001; Yon 2000), this paper will scrutinize the combustible intersections between such new regimes of security and surveillance and prevailing theoretical concepts of space and I.D.ology.

In the current political moment of homeland (and otherland) safety and security $(\mathrm{USA})^{\mathrm{iii}}$ and emergency preparedness (Canada) $)^{\mathrm{iv}}$, there is unprecedented attention being paid to the containment, movement, and dispersal of people in public spaces. The interplay of global and local spatial practices has never been quite so acute in the North American context of public institutional life. From this, a new security emerges, one in which the calculation of potential risk calls for a re-articulation, and indeed an invention, of new disciplinary technologies. Here, we use disciplinary technologies in the Foucauldian sense to mean the strategies of power and control over people and spaces and the rationalization of techniques to serve that end.

Examining some contemporary and troubling trends within the mass schooling systems of Canada and the U.S, we argue that recent neo-liberal discourses of “emergency preparedness" (official Canadian government discourse), "homeland security" (official U.S. government discourse), "safe schools" and "zero-tolerance (official Canadian and U.S. public school policy discourses) ${ }^{\mathrm{v}}$, enable public spaces, and especially public schools, to be produced in ways that corroborate neo-liberal ideologies. These ideologies, and the policies that proceed from them, place a premium on security, police the borders of home/school, and prevent the penetration of the other/ the outsider/ the risk, in everyday life. We are playing on the term 'ideology' in the title, precisely because these, now common practices, in schools and Western societies more generally, 
I.D.ology and the Technologies of Public (School) Space:

\section{An ethnographic inquiry into the neo-liberal tactics of social (re)production}

require an unrelenting self-consciousness of one's identity, a material and (geo)graphic verification of one's 'authentic' self. While historically and philosophically, the term 'ideology' has two referents- one morally neutral as in 'ideational', the second given a negative moral valence, as in false consciousness or obfuscation- we take the term in marriage with the above-named and other social/school policies that embed the notion of risk and in/security. And we use the term 'neoliberalism' in its broad sense clearly articulated by Giroux (2005, p. 5-6); that is, as 'the hegemonic ideology of our time [that], much more than an economic theory, can also be defined as a cultural politics that has created an array of institutions and public spheres from which to produce, disseminate, and secure its ideologies, values, and views of the world'.

\section{The Archi-technologies of Public Space: a theoretical frame}

Space is a social morphology ... To picture space as a 'frame' or a container into which nothing can be put unless it is smaller than the recipient, and to imagine that this container has no other purpose than to preserve what has been put in it this is probably the initial error. But is it error or ideology? The latter, more than likely. If so who promotes it? Who exploits it? And why and how do they do so? (Lefebvre 1991, p. 94)

Lefebvre's questions above point to the ways in which we have conceptualized space in this paper. We want to think about how governments and school boards, in the neo-liberal order, exploit the spaces of schools, in order to maintain the boundaries between legal citizens and dangerous 'others'. In this account of the new security measures in New York and Toronto 
I.D.ology and the Technologies of Public (School) Space:

\section{An ethnographic inquiry into the neo-liberal tactics of social (re)production}

schools, and the bureaucratic measures that must be negotiated in order to access these schools, we suggest, in the Lefebvrian (1991) sense, that the scanning systems, the identification procedures, and new organizations of space are the material realization of security ideologies. It was Lefebvre (1991) who first introduced the concept of 'social space.' Social space 'incorporates social actions' (p.33). Social space is not just space in itself, it is not a frame nor a container that is designed simply to receive whatever is poured into it (pp.93-94). On the contrary, for Lefebvre, social space 'is at once work and product - a materialization of 'social being”' (p.101-102). According to Lefebvre (1991) all societies 'secrete' space, producing and appropriating it as they go along. Lefebvre's text, The Production of Space, translated from French in 1991, appeared to be a catalyst for an interest in the field of cultural and human geographies. Although his work has been critiqued for its structural dualism, its celebration of heterosexuality, and lack of race analysis (Shields 2004), his theorizing of the production of space enabled the development of theories of space that investigate the links between everyday spatial practices and various socio-cultural relations in (post)modernity. For instance, in the last decade there has been a focus on aspects of space and the construction of subjectivities with respect to: identity and the body (Nast \& Pile 1998, Razack 1999); resistance in space and place (Pile \& Keith 1997; Mitchell 1995; Ruddick 1990, 1997; Sibley 1995); the gendering of space (Duncan 1996; Massey 2000); space and the performance of sexuality (Bell, Binne, Cream \& Valentine 1994; Bell \& Valentine 1995; Colomina 1992; De Lauretis 1998; Grosz 1995; Valentine 1996) and; how space is produced through racialized practices and (neo)colonialism (Mohanram 1999; Razack 1998, 2000a, 2000b).

How does the governance of space and the organization of architecture interlock in the space of schools? "The $3^{\text {rd }}$ floor's dangerous. Mind you, there's more security on that floor" 


\section{An ethnographic inquiry into the neo-liberal tactics of social (re)production}

(Grade 11 student, Queens, New York). Lefebvre (cited in Forty 2000) states that architecture's 'space-regulating operations serve not its own ends, but those of power in general' (p.275) and that architects are mediators in discourses of spatial power (Lefebvre 1991). While, traditionally, architecture has been viewed as the design and production of buildings, which are then discussed by critics as self-contained objects in terms of style and aesthetics (Allsopp 1977; Scruton 1979), other critical theorists have examined how both buildings and architectural practices are articulations of political, social, and cultural ideologies (Hollier 1992; Foucault 1977, 1980, 1997; Grosz 2001; Markus 1993; Rendell, Penner, Borden: 2000). In fact, cultural studies of architecture have recognized that architecture continues after the moment of its design and construction: architecture is experienced, appropriated, perceived, and occupied, thus, architecture is seen to be important in the construction of subjectivities (Dovey 1999; Lahiji \& Friedman 1997; Markus 1993; Whiteman, Kipnis \& Burdett 1992). As such, architecture is considered a form of cultural documentation that contains representations of gender (Rendell 2000; Wigley 1992), sexuality (Foucault 1978; Colomina 1992; Ingraham 1992), class (Markus 1993) race, and Western formal aesthetics and ideologies of empire (Apter 1998; Burns 1997; Celik 2000; Nalbantoglu \& Wong 1997; Wilson 1998). These later works demonstrate that theorization, techniques of representation and production, as well as social, political, and economic factors are key to the generative processes of architecture. Considering these intersections is particularly relevant here because it allows us to think of urban schools and security at the intersections of subjectivity, architectural design, representation, regulation, power, and ideology.

In Discipline and Punish, Foucault (1977) demonstrates that eighteenth- and nineteenthcentury (European) architecture was linked to the aims and techniques of the government of 
I.D.ology and the Technologies of Public (School) Space:

\section{An ethnographic inquiry into the neo-liberal tactics of social (re)production}

societies. He suggests that great attention was paid to the layout of cities, and public and private spaces. He argues that school buildings were scrutinized because it was important that 'educational space function like a learning machine' (p.147), and that it function to distinguish between students' worth, character, and progress. The organization of space in schools (i.e., rows of desks, corridors, courtyards, entranceways) form a perpetual grid for the organization, supervising, and hierarchizing of individuals. Furthermore, in the History of Sexuality, Foucault (1978) suggests that the architectural layout of schools demonstrated a pre-occupation with children's sexuality, the classroom spaces, the planning of lessons, the distributions of partitions and tables were 'largely based on the assumption that this sexuality existed, that it was precocious, active, and ever present' (p.28). While this paper is not concerned with youths' sexualities, we want to argue that spatial distributions in schools that characterized eighteenthand nineteenth- century European bourgeois concerns for discipline, learning and sexuality are now more forcefully directed toward the problem of identifying potentially dangerous and criminal others. In fact, we would suggest that the ways in which the 'problems of sexuality' and the 'problems of discipline' were addressed in nineteenth-century schools, are the obvious antecedents to the ways in which security is now produced and managed. While Foucault most certainly developed his ideas of discipline, power and spatial organization for a specific time and place - emphasizing the way a whole host of institutions emerged in the nineteenth century, bearing important resemblances to one another, such as the school, the prison, and the hospital his work remains important in the mapping of 'many of the more questionable contours of the present' (Philo 2004, p.124).

What are the questionable contours of the present? First, all those who hold a measure of authority are placed in a state of perpetual high alert. Scanning systems, and other security 


\section{An ethnographic inquiry into the neo-liberal tactics of social (re)production}

procedures, are based on the assumption that criminality is active and ever present. Second, space is, thus, designed to communicate the message that transgressors, deviants, or those who threaten the social and spatial order have no place here. "They stick us in the 'sweep room' just because we missed the bell by 2 seconds. It's ridiculous" (Grade 12 student, Queens, New York). To paraphrase Foucault (1978), pedagogical institutions, in these times of heightened security and alert, have multiplied the forms of discourses on the subject of security; they have established various points of implantation for criminality and danger; they have coded and (dis)qualified (un)worthy individuals; and they have made clear the difference between same (accepted conventions for thought and action) and other (unacceptable mass of activities of those who slip beyond the boundaries of what is 'normal') (Philo 2004). Thus, we agree with Hollier (1992) when he states:

... nothing becomes legible unless it is submitted to the architectural grid.

Architecture under these conditions is the archistructure, the system of systems.

The keystone of systematicity in general, it organizes the concord of languages and guarantees universal legibility. (p.33)

With this in mind, we suggest that the architectural and spatial practices in these schools, and in other public institutions, work to produce new experiences of subjectivity and space, through the creation of particular strategies of security and spatial practices of order and regulation. In an empirical study of an urban university athletic centre space, (second author, 2003) illustrates that even in some of the most mundane spaces (changing rooms), technologies of power - surveillance, classification, normalization, spatial distribution, and regulation - operate. (Second author) demonstrates that concerns about risk, deviance, and transgression are ever present. In 


\section{An ethnographic inquiry into the neo-liberal tactics of social (re)production}

fact, the architectural arrangements of locker rooms (e.g., angular, straight edges, the preponderance of open showers, and mirrors) and the surveillance strategies enabled by these arrangements (e.g., staff use the mirrors to perform quick visual sweeps of the locker room) function to keep everyone on high alert and in their place. As one participant in the study remarked: 'There are a lot of eyes on this space!' This functions to remind the subjects of space that constant vigilance is required, and is in place, to guard the property, propriety, and health of the social body. Likewise, school architecture, with its long corridors and contained classrooms, for example, produces particular 'social spaces' that contribute to the regulation of behaviours. If we see schools as performing particular spatial practices that make use of an array of architectural arrangements and surveillance technologies to survey and document the movement of individuals, then we might also say that the archi-technologies of schools are fully embedded in systems of domination that guarantee the legibility (i.e., the identification) of all the subjects who move in, and through, those spaces:

Fieldnote Excerpt May 13, 2004

A metal, windowless door, with "welcome" in bright blue. But it's locked. Kids can't get in. Neither can we. A black parent arrives with us. She also sighs at the locked door. When we're admitted, we collectively bemoan the security system. A security guard overhears us and says that there are teachers in New York who won't teach in a school without security. I say it's a shame and he and the parent explain that they're "safer" and, besides, "it's a different world now". The parent then offers, "They need Jesus, that's the problem". I ask why they feel safer here and the guard says that in other schools every kid could have weapons.

New archi-technologies (i.e., security gates, metal detectors, portable wands, holding rooms for students/visitors, school building configurations, scanners and security cameras) are the material manifestations of the fears that dominant groups have about members of 'risky', and/or marginalized groups. These technologies are fundamental to 
I.D.ology and the Technologies of Public (School) Space:

\section{An ethnographic inquiry into the neo-liberal tactics of social (re)production}

the exercise of power in modern societies. Foucault's (1977) concept of disciplinary

power moves away from analyzing power as only administered centrally from one dominant group to thinking about power in the micro-level interactions between people and bodies. Foucault provides evidence to show that disciplinary techniques surveillance, normalization, individualization, and examinations - are key to the functioning of power. He suggests that power circulates, that it is productive, that 'it produces reality, it produces domains of objects and rituals of truth' (p.50). Foucault argues that disciplinary power emerged with the advent of modern institutions such as schools and other institutions in the nineteenth century. Schools still embody aspects of this function, that is, disciplining regimes, which seek to mould and reform their subjects, making useful, calculable, responsible citizens. Yet, simultaneously a different regime of power is being overlaid. In these schools, the functioning of power produces new kinds of social spaces and new kinds of identities, all circulating within the discourses of security and risk. Concomitantly, new security practices are as concerned with excluding and expelling danger as they are with reforming behaviour. Institutions of discipline and schooling are now being articulated within new neo-liberal practices of risk management, surveillance, and identity control.

There are many theorists who have examined the links among power, control, policing, risk, risk management, subjectivity and otherness in neo-liberal societies (Beck, 1992; Dear 1999; Castel 1991; Lupton 1999; O’Malley, 1996). These authors understand risk as a governmental strategy of regulatory power by which individuals are monitored and managed through the goals of neo-liberalism (Lupton 1999), which enable a 'potentially infinite multiplication of the possibilities for intervention' (Castel, 1991, p. 


\section{An ethnographic inquiry into the neo-liberal tactics of social (re)production}

289). Of course there is no one, homogeneous approach to risk management with respect to intervention strategies. Strategies differ depending on what kind of risk is identifiedenvironmental, epidemiological, insurantial, for instance - but it would appear that neoliberal societies are returning to previous forms of discipline, such as coercion and punishment, as individuals and social groups are identified as being either 'at risk' or imposing risk upon others (Lupton 1999).

What is clear is that technologies of mass surveillance, like those used commonly in North American schools, are central to the constitution of spaces of risk and security and these technologies work to construct new understandings of bodies in space and time. As Lupton (1999) states: 'Discourses of risk, then, are directed at the regulation of the body: how it moves in space, how it interacts with other bodies and things' (p.88). These discourses, in turn, contribute to the constitution of new kinds of subjectivities: selfregulating individuals who take up governmental imperatives, and new kinds of spaces, which are highly policed and regulated to ensure that members of threatening groups are removed (Lupton 1999). It is these kinds of risk management strategies that are prevalent in the (re)organization of schools in times of 'emergency preparedness' and 'homeland security'.

To summarize, Foucault $(1977,1978)$ made many observations about the operation of power in educational institutions. In relation to schools, he argued that buildings are not just concrete spaces for organizing individuals, but that buildings, architectural arrangements, and spatial organization (i.e., corridors, halls, classrooms) are mechanisms of power reduced to their ideal (spatial) form. What we are now seeing is that spatial arrangements of schools are, in fact, no longer governed by the physical 


\section{An ethnographic inquiry into the neo-liberal tactics of social (re)production}

architectural boundaries alone, they are governed by sophisticated systems of electronic surveillance. In fact, Virilo (1997) suggests that architecture itself has little to do with individual architects' power over the building per se; recent design, he argues, has emerged from perceived public security requirements. We live, according to Virilo, in overexposed cities, and we would add, overexposed public school environments. School archi-technologies, then, can be read as strategies of (spatial) inclusion and exclusion that 'are often explicitly concerned with maintaining certain bodies within geographical limits' (Lupton 1999, p.142). The school gate gives way to the security gateway.

Critical Episode I: Field Note Reflection, Jamaica Queens, New York City January 16, 2004

'At least we know we're safe in here. Normal fights but no weapons and the kids are totally used to it' (Teacher, January 16, 2003).

Arriving at one of the study sites, I (first author) approach the school. Large, hanging banners outside the school exclaim: 'New York School of Excellence' and another 'Theatre and Education Award for Excellence'. Solid metal doors, where windows used to be, at this main entrance. I enter with the pack of students. Each of us, teachers, students, and Canadian visitors line up to proceed through the security process, carefully placing our bags on conveyer belts, passing through the metal detectors and frisked by the wand scanner on the other side. Once admitted, I must check in with the police officer on the other side of the door. No 'Athlete of the Year' pictures, no Valedictorian Addresses donning these walls. In the 'holding area', I show my picture i.d. and sign in, as a visitor. While I am doing this, droves of young people are swiping 


\section{An ethnographic inquiry into the neo-liberal tactics of social (re)production}

their identification cards and I am watching their mostly black and brown faces appear on a large computer screen, authenticating their identities. Suddenly, a loud computeranimated voice calls out: 'This student is suspended. Stop this student'. A young irritated-looking black girl gets pulled aside by a teacher and is loudly interrogated. I am amazed by the efficiency of this system. And by how unremarkable it all seems to these young people.

I finally meet the teacher whose classroom I will be observing this day. 'That's quite a welcoming committee in the foyer', I quip. 'Well you wanted an urban school', he replies in all seriousness. And then further explains, 'At least we know we're safe in here. Normal fights but no weapons and the kids are totally used to it'.

The teacher introduces me to the student 'spokesperson' for the school. I ask her what she is called on to speak about and the teacher-not the student-explains that she has recently represented the school very well when the media decided to do a piece about how this school had turned its violence around through the installation of the 'scanning system'. Well that and 'operation clear sweep'. This, he explains, is a drill whereby the principal randomly calls for an 'operation clear sweep' over the public address system and ALL students must clear the halls immediately or be taken down to the office for 'disciplinary measures'. 'It really makes us feel safe', he explains one last time.

Many theories of space examine how public space is mapped in order to create areas of security while keeping disorder and non-normative others contained (Razack 2000a, 2000b; Ruddick 1990, 1997; Sibley 1995; Valentine 1997). The architechnologies of space, such as identification-verification systems and security gates, enable spatial arrangements to be used continuously to monitor the circulation and flow 


\section{An ethnographic inquiry into the neo-liberal tactics of social (re)production}

of individuals. Monitoring produces what Deleuze and Guattari (1987) might call 'striated space.' 'Striated space' is space that is regulated and highly organized; it is delimited and closed. Striated space is grid-like, movement is confined and limited to preset paths, subjects are fixed and identifiable. It is important to acknowledge that public spaces are fragmented and are sites of contestation, that is, marginalized groups may occupy and experience public spaces differently (and in transgressive ways) from those intended by (dominant groups') measures of public order (Delaney 1994). It appears, however, that for students and staff (and even visiting researchers) in this school, the possibilities of knowing space outside dominant regulatory and disciplinary structures are becoming more and more limited. The production of striated space enables certain bodies, those marked in some way by certain classificatory categories (class, race, ethnicity, gender, sexuality, age, disability, criminality, 'under suspension' etc.), to be deemed out of place, and to be made more visible. Given that ' $\ldots$ the ways in which we live out body/place relationships are political' (Nast \& Pile 1998, p.2), what we clearly see in this hyper-security-conscious school is that: 'Bit by bit, bodies become relation, territorialized in specific ways. Indeed places themselves might be said to be exactly the same: they, too, are made-up out of relationships between, within and beyond them; territorialized through scales, borders, geography, geopolitics' (Nast \& Pile, p.4). In the case of our transgressing student, accused of being under suspension, her only crime (if we are to trust the system) appears to be an attempt to return to school prematurely. We do not know (nor is it our business, those of us witnessing this public interrogation) why she is suspended. Neither can we know whether the system is malfunctioning on this day, a data entry error perhaps? The girl may be perfectly entitled to return to school. Or, 


\section{An ethnographic inquiry into the neo-liberal tactics of social (re)production}

she may, in fact, be circumventing her punishment (i.e., short-changing her suspension) in which case, what we do know is that the system does not discriminate between 'real' crimes (an 'intruder' attempting to enter the school or a student armed with a weapon, for instance) and minor infractions (wearing a hat, carrying a cell phone, speaking disrespectfully or returning from a suspension prematurely). What we are suggesting here is quite simply that the punishment does not suit the crime, the reaction does not suit the reality, the public harassment is unwarranted. Yet these practices and technologies are normalized, naturalized, and literally come under the radar. Our perspective is skewed when these relatively unthreatening behaviours are criminalized and positioned as security threats. The technological mechanisms that the students, staff, and researcher(s) are subjected to ensure that the school becomes protected space. These mechanisms are an essential part of the strategies used by dominant groups (in this case, school administration and private security companies) to police the public space of the school. Members of threatening groups (i.e., threatening to school property, to other school members, or even to school disciplinary procedures) are identified, restricted, and denied entry to this educational space. The space of the school, in which these threatening individuals and/or groups (might) move about, becomes potentially 'dangerous' posing an increased risk of criminal activity. While there are, undeniably, real material consequences to violence and/or weapons in schools, here, the ever-present anticipation of risk has resulted in increased surveillance, security guard presence, and vigilance on the part of those who inhabit, and are inhabited by, this increasingly privatized space. In such a way, the school, and its architectural layout, acts as a 'functional site;' this creates 


\section{An ethnographic inquiry into the neo-liberal tactics of social (re)production}

a permanent grid of security that eradicates any confusion over what is legal and/or illegal in this space (Foucault 1977).

To further extend this argument, Foucault (1977) proposes that the maintenance of discipline and order (in modernity) requires that individuals be distributed in space, he calls this 'the art of distributions.' Foucault's examination of prisons, schools, and other public institutions concludes that 'the art of distributions' requires that several techniques - enclosures, partitioning, and functional sites - be employed to organize the new economies of bodies and spaces. These help:

... to establish presences and absences, to know where and how to locate individuals, to set up useful communications, to interrupt others, to be able at each moment to supervise the conduct of each individual, to assess it, to judge it, to calculate its qualities or merits. (Foucault, p. 143)

As such, and as the researcher (first author) experienced through her room assignment, in these new highly regulated spaces, 'each individual has his [sic] own place; and each place its individual' (Foucault 1977, p.143). Or, in the case of 'Operation Clear Sweep', 'safe' space is also produced by removing, on command, all individuals from common, open space. Foucault's (1977) analysis of plague quarantine is useful here to deconstruct the functioning of power inherent in 'Operation Clear Sweep.' He states: 'each individual is fixed in his [sic] place. And, if he [sic] moves, he [sic] does so at the risk of his [sic] life, contagion or punishment' (p.194). 'Operation Clear Sweep' imposes a kind of quarantine or curfew on students. The open, more public spaces of the school must not be transgressed. All movement is monitored; violators are subjected to disciplinary procedures. In addition, the scanning system not only operates as a machine for 


\section{An ethnographic inquiry into the neo-liberal tactics of social (re)production}

supervising and identifying individuals, it rewards those who can pass through the gates;

the reward: freedom to enter and not be picked out, 'ratted on' by the scanning-computer. However each student, staff member, and/or researcher, who successfully negotiates the scanning system, is then limited and governed inside the gated school. Importantly, however, disciplinary technologies not only control, subdue and discipline individuals, they also make virtuous, productive, healthy, safe, enterprising, and empowered individuals (Rose 1996). Indeed, Foucault's concept of governance, or more accurately 'governmentality,' has been defined as 'the contact between the technologies of domination of others and those of the self' (Foucault 1988 in Fox 1994, p.32). The dissemination of these disciplinary technologies into public space, then, secures, and is also secured by, the active participation of individuals in the very disciplinary mechanisms that measure, classify, normalize, and potentially exclude them. Teachers, students, administrators, and caretakers are both the subjects and the guardians of social

space. ___ 's (second author, 2003) spatial ethnography of a university athletic centre changing room clearly demonstrates this latter point. Indeed, she found that individuals are both enabled and constrained by, in this case, public health ideologies that operate on, and govern, social space. She concluded that people - who administer, clean, and use institutionalized recreational space - derive pleasure from maintaining the ideological ordering of space. In other words, each 'worthy' individual gains from the architectural, spatial and security arrangements in some way - these are the necessary material and subjective conditions for the establishment of what is understood, in schools, as safety and liberty. 
An ethnographic inquiry into the neo-liberal tactics of social (re)production

Critical Episode II: Field Note Reflection:, Brooklyn, New York January 14, 2004

'This computer thinks that's some kind of alien address M'am. I can't accept that' (Fingerprinting Agent, Department of Education, Brooklyn, New York).

The "dangerous class", is what Italian philosopher and political theorist, Giorgio Agamben has called us. Professor Agamben was due to arrive in January 2004, to take up a visiting scholar appointment at New York University. And as a distinguished professor being honoured by the university, he was scheduled to offer an intensive graduate course. But Professor Agamben cancelled his trip as protest against the new American policy of fingerprinting for visitors and employees from other countries.

Professor Agamben, speaking recently to Le Monde in Paris, suggests that we have been made into 'the ideal suspect'. The New York Times (Saturday January 17, 2004, B4) went on to report that Dean Foley, of the Faculty of Arts and Science at N.Y.U., was '...eager and hopeful that in future years he can take up the appointment again'. I am not convinced that there will be such a return to innocence that the Dean Foley is counting on.

As a Canadian researcher, I (first author) made it through 'Homeland Security', through U.S. customs at Pearson International Airport in Toronto, and on to my New York City destination. I was not fingerprinted, nor did I have my retina scanned, although I did need to explain in some detail how I had met the friends with whom I would be staying during my time in Manhattan. 'At a play' was not what the customs agent was expecting, but sufficiently benevolent sounding, I suppose. My surveillance nightmare began once I arrived, however. 


\section{An ethnographic inquiry into the neo-liberal tactics of social (re)production}

The demand to have all security approvals in place delayed the New York piece of my study by eighteen months. Despite undergoing an extensive ethical review process at the University of Toronto, another process entirely was required by the New York Department of Education in order to gain access to New York schools. And that process involved a fingerprinting ordeal, the likes of which I could not have previously fathomed.

No one expects a smooth process with such bureaucratic procedures and mine was no exception: A crowded waiting room with no instructions apparent; unclear forms to be filled in; rooms to pass through in no obvious order. I was ordered to stay seated until it was my turn, but no one knew whose turn it was, nor in what order and to which rooms we should be proceeding. After an hour's wait, with people all around explaining to one another that they were here because of a job requirement, that there was no 'other' reason they were being fingerprinted, I was finally called to a desk. Evidently, the computer system is unequipped to register addresses outside the U.S. It could not accept a Canadian postal code and I had no zip code to offer. We were unable to proceed to the next screen and therefore I could not be fingerprinted, the clerk explained calmly. Actually, she said 'this computer thinks that's some kind of alien address M'am. I can't accept that'. After offering my friends' address with an appropriate zip code, we were able to proceed. It was a rather protracted experience and having never been fingerprinted before, I couldn't agree more with Professor Agamben. I was the 'ideal suspect', with an 'alien' address. But this, I would learn, is really nothing compared to what high school students are subjected to every day.

What we are seeing in schools- and in the bureaucratic procedures one must submit to in order to access these schools- is how investments in security and discipline are remaking individuals (and communities) in terms of how they might potentially 


\section{An ethnographic inquiry into the neo-liberal tactics of social (re)production}

contaminate, terrorize and/or abuse the measures of public and spatial order in schools.

Foucault's (1977) theorizing of the panopticon is useful here because it demonstrates how power can work to produce disciplined and docile (subjected and useful) bodies; bodies that can be regulated in time and space. Foucault based his concept of the panopticon on Jeremy Bentham's design of a (panoptic) circular prison (circa 1840's) that was supposed to act in such a way that prisoners would be totally visible to prisons guards, yet, prisoners could never be entirely sure whether or not they were being observed. Conceptually, the panopticon is:

... enclosed, segmented space, observed at every point, in which the individuals are inserted in a fixed place, in which the slightest movements are supervised, in which all events are recorded, in which the uninterrupted work of writing links the centre and periphery, in which power is exercised through division, according to a continuous hierarchical figure, in which each individual is constantly located, examined and distributed ... (it) constitutes a compact model of the disciplinary mechanism. (p.197)

In order for the panopticon, and its mode of surveillance, to operate efficiently and effectively, permanent registration is necessary (Foucault 1977). Fingerprinting - the examination of one's 'authenticity' - objectifies each individual and makes him or her a 'case'; it documents his/her possible use or potential abuse of the homeland. In this climate, the process of fingerprinting, formerly reserved for criminals, is normalized. And these examinations ensure that individuals are embedded in a field of documentation; a meticulous archive, of dangerous, and not-so dangerous, classes of individuals and groups. If your zip code cannot be verified, if here is not your home, if you hail from 


\section{An ethnographic inquiry into the neo-liberal tactics of social (re)production}

elsewhere, then you cannot proceed. As such, this bureaucratic, disciplinary, and panoptic mechanism:

. . .arrests or regulates movements; it clears up confusion; it dissipates compact groupings of individuals wandering about the country in unpredictable ways; it establishes calculated distributions. (Foucault 1977, p.219)

In the fingerprinting waiting area, and in schools and other public institutions, each individual tries to assure the other that they are being fingerprinted and scanned for legitimate reasons. Foucault (1977) suggests that the 'beauty' of the panoptic system is that it works at its fullest potential when self-surveillance occurs. Because individuals are never sure if they are being observed, they then begin to regulate their own behaviour in order not to be caught out. This is an enormously efficient system for the administration of power, control and risk management because:

... it automizes and disindividualizes power. Power has its principle not so much in a person as in a certain distribution of bodies, surfaces, lights, gazes; in an arrangement whose internal mechanisms produce the relation in which individuals are caught up. (Foucault 1977, p.202)

It is through an array of panoptic disciplinary mechanisms, then, that each individual comes to know her/himself and others, his/her own and others' proper distribution in space. Full co-operation only requires a/the finger, not as a gesture of resistance or subversion, but as a gesture of verification of good citizenship, with fixed (homeland) address, and no previous (dangerous) record. Participation in disciplinary mechanisms confirms our investment in homeland security and school policing. If, as Foucault (1977) argues, individuals are a fabrication of the technologies of power, then we suggest that worthy citizens become points of application for security ideologies. Deeply embedded in the disciplinary mechanisms and discourses of security, risk and power, students and 


\section{An ethnographic inquiry into the neo-liberal tactics of social (re)production}

(fingerprinted) workers (and researchers) depend on these discourses for their continued existence and affirmation. In fact, being a subject means being subjected to discourses we rarely choose, but, paradoxically, this subjection initiates and sustains our agency (Butler 1997). Thus, we are all implicated in these ideologies and in the territorialization of space and 'unworthy' others. Anything else would result in our eviction.

\section{Implications and Conclusions}

'How does knowin' my business make you any safer'? (Student, Toronto High

\section{School) $)^{v i}$}

Amidst a lively classroom discussion in a downtown Toronto school, one young Black woman blurts out this question. Young bodies in urban Toronto schools are asking their teachers, principals, and each other, why new policies are policing what they wear, how they move, and whether they 'belong'. Killian's (1998) theorizing of public and private space is useful here. He argues that we should not rely on binary notions of public versus private. Rather, he suggests that we must analyze environments with respect to 'power of access' and 'power of exclusion'. The female student's retort not only challenges her fellow student, but also questions an entire school system that is, ever-increasingly, dependent upon the continuous recording, monitoring, and archiving of students' personal lives. These school policies permanently register details of students' private lives (Ontario schools maintain OSRs- Ontario Student Records- on all school-age students in Ontario. These records follow them from school to school), and make those lives public (school) property.

In one Toronto school, the year-old and greatly despised "No Hat" policy has given way to a storm of protest from young people. Particularly youth of colour insist that 


\section{An ethnographic inquiry into the neo-liberal tactics of social (re)production}

this particular policy is not only unfair and over-zealous, but that it is racist too. The

(White) Goth students are not forbidden to wear their spiked necklaces and bracelets, but the Black students cannot wear skull caps, dew rags, bandanas or caps. The colours of bandanas are believed to be associated with gangs, and therefore, can incite violence in schools, they are told by administrators. Not missing the irony, the Black students note that their 'attire' is associated with gang-related activity, even though most popular depictions of the gun-wielding students in Columbine were 'Goth' (White faces, black trenchcoats) in their appearance. While some forms of surveillance, like I.D. scanner machines seem undiscriminating in their procedures, others, like the policing of clothing in the interest of 'safety' seem, to many students, targeted toward certain (minoritized) students and not others. During this animated classroom discussion, one (White, male) student, with a comic turn, quipped that the 'no hat' rule might have a positive effect because if there was a masked killer lurking on school property, he would be stopped by a teacher: 'Remove your hat, it's a school rule!' This young man has, perhaps, the possibility of seeing this 'dangerous other' as someone outside the school, someone for whom he could not possibly be mistaken. For others, this is not so easy.

We are well aware of the symbolic and very real violence that exists in schools in Canada and the U.S. Weapons in schools lead to serious, sometimes fatal, consequences for youth. Schools need to be safe for young people and teachers. Students and school personnel, too, have a right to be free from harassment, but how we go about making safer and more humane school corridors and classrooms for young people is of equal importance. Youth have very few avenues of recourse in schools, very limited ways to register their dissatisfaction with policies and procedures. In one classroom at a Toronto 


\section{An ethnographic inquiry into the neo-liberal tactics of social (re)production}

school, over $50 \%$ of the students in a grade 12 English class had $0 \%$ going into the final exam. They had $0 \%$, according to their teacher, because they were never there. The chronic absenteeism in this school might be a sign of student apathy, as is often suggested, but it might also be the result of increased efforts to keep the 'undesirables' out. One student at the school explained that she felt safe at the school because 'most of the people who make it unsafe never come'.

School administration teams need to respond to the terrifying acts of violence we have witnessed in schools in the U.S. and Canada, in the recent past. But there is no question that one is made to feel criminal in these instances of extreme surveillance and as long as people/schools remain convinced that these technologies of security make them safer, we would not like to speculate about how these 'safety measures' might be amplified and rationalized with very little consideration of their impact on our collective psyche. On the question of striking a balance between security and personal privacy in schools, another young Black woman in a Toronto school exclaimed: 'Yeah but now with the way it is, you can't even be yourself and school is where you're supposed to be yourself'. Yon (2000) in his critical ethnography of a Toronto school calls this a 'spoiled identity', when the expectations of certain students and certain schools are so low as to completely marginalize and disempower them. Now- in the new criminalized environments of high schools- these students are not only unlikely to produce anything of worth, but they are also imagined to be lurking around the next corner, just waiting to transgress some rule or cause harm to others. Research does tell us that young people often play the roles they are given; as students in a 'New York City School of Excellence', we would certainly be troubled by how the day begins. Until, of course, we 


\section{An ethnographic inquiry into the neo-liberal tactics of social (re)production}

become numbed by the repetition of the experience and we routinely open our bags, feel

the prying surface of a weapon-searching wand, and scan and verify our identity. All before period 1.

The New York Times recently reported on a performance artist who has developed a tour of all the disguised surveillance cameras lurking in New York neighbourhoods. By his count, the number of surveillance cameras has tripled in the last five years, driven by an increase in private cameras (The New York Times, January 17, 2004, B1). His form of protest is to perform in front of these cameras, along with his group, known as the 'Surveillance Camera Performers'. He claims these cameras have turned us all into performers, so that is just what they will do. The Surveillance Camera Performers are resisting 'the art of distributions' with their own distribution of the arts. Satire aside, we have found in our research that the drama classroom often produces the kind of space where voices of dissent and resistance can be productively explored, but that is a subject for another paper.

Canadian schools seem to have not, yet, adopted the same degree of surveillance that is commonplace in New York schools. But many Canadian schools have already installed metal detectors, video camera surveillance, and have implemented I.D. tags. A culture already fearful of youth, exacerbated by sensational media reports across the country, has served to rationalize a regime of security measures while, unsurprisingly, entrenching a criminal view of urban youth in and outside schools. Security measures are remaking schools; they are becoming, or perhaps reverting to, correctional facilities for the training of a new generation of citizens in the arts of urban, national conduct. In other 


\section{An ethnographic inquiry into the neo-liberal tactics of social (re)production}

words, those in schools are kept safe and protected for their own good. And this new generation of citizens confronts fear, risk, and surveillance (of self and others) every day.

We are well prepared to admit that issues of security and safety in schools need a serious re-thinking, but we must also pay careful attention to the new ways in which risk management in schools and public institutions, to paraphrase Foucault (1977), characterizes, classifies, distributes individuals along a scale, around a norm, how its strategies hierarchize individuals in relation to one another and, if necessary, disqualifies and invalidates them (p.223). The notions of risk and otherness- and the potential exploitation of real fears- that we have explored in this paper are easily extended to other public institutions like universities, hospitals, community and recreation centres, shopping malls, parklands, and street corners. What is important to note is that in this intensified climate of homeland (and school) security, spatial arrangements- and the technologies that operate in space- still establish who is respectable and who is not. It is clear, from the experience of fingerprinting, airport customs, and school I.D. scanning, that 'space determines who belongs to the nation state and who does not' (Razack 1998: 367).

What is the role ethnography plays in understanding contemporary discourses and their attendant practices? Ethnographies, such as the one that has provided the material experiences for this conceptual exploration, can provide accounts of everyday practices in education that are implicated in social (re)production. Analyses of these accounts, such as the critical episodes outlined in this paper, expose- ironically- the invisibility, the naturalizing of such policies. These policies in practice are not simply inconveniences to be endured. What we hope to have illustrated in this paper is how schools still clearly embody aspects of disciplinary functions, such as those articulated by Foucault in his 


\section{An ethnographic inquiry into the neo-liberal tactics of social (re)production}

genealogy of discipline and power, as examined through analyses of a range of $19^{\text {th }}$ social and political institutions, but also how a different regime of power is being overlaid through new practices of risk management, surveillance, and identity control.

Ethnography as an orientation and set of methodological practices, promotes the possibility of interpretation and critical understanding. In its finest moments, it may even create the conditions for intervention in current policies by critiquing and demonstrating the idea that these policies, while promoting a certain kind of social order, also obviously fortify the self/(dangerous)other binary and limit the possibility for a critical, democratic citizenry. To propose new norms of justice, embedded in concrete educational policy is clearly the next step and, decidedly, the work of another paper. 


\section{An ethnographic inquiry into the neo-liberal tactics of social (re)production}

\section{References}

Allsopp, B. (1977). A modern theory of architecture. London, Routledge \& Kegan Paul.

Apter, E. (1998). Harem: Colonial fiction and architectural fantasm in turn-of-the-century

France. Places through the body. H. Nast and S. Pile, Eds. New York, Routledge: 119-132.

Beck, U. (1992). Risk society: Towards a new modernity. London, Sage.

Bell, D., Binne, J., Cream, J. and G. Valentine. (1994). 'All hyped up and no place to go'.

Gender, Place \& Culture 1: 31-47.

Bell, D. and G. Valentine, Eds. (1995). Mapping desire. Geographies of sexualities.

London, Routledge.

Burns, K. (1997). A house for Josephine Baker. Postcolonial space(s). G. Nalbantoglu and

C. Wong, Eds. New York, Princeton Architectural Press: 53-72.

Butler, J. (1997). The psychic life of power. Theories in subjection. Stanford, CA, Stanford University Press.

Castel, R. (1991). From dangerousness to risk. The Foucault effect: Studies in

governmentality. G. Burchell, C. Gordon \& P. Miller, Eds. London, Harvester/Wheatsheaf: 281298.

Celik, Z. (2000). Excerpts from 'Le Corbusier, Orientalism, colonialism'. Gender, space, architecture. J. Rendell, B. Penner and I. Borden, Eds. London, Routledge: 321-331.

Colomina, B., Ed. (1992). Sexuality \& space. New York, Princeton Papers on Architecture, Princeton Architectural Press.

Dear, M. (1999). Governmentality: Power and rule in modern society. London, Sage.

DeLauretis, T. (1998). Perverse desire. The lure of the mannish lesbian. Places through the body. H. Nast and S. Pile, Eds. New York, Routledge: 230-243. 


\section{An ethnographic inquiry into the neo-liberal tactics of social (re)production}

Delaney, J. (1994). "Public space of publicity?” a/r/c - architecture/research/criticism 1994-1995: 2-5

Deleuze, G. and F. Guattari (1987). A thousand plateaus. Capitalism and schizophrenia. Minneapolis, University of Minnesota Press.

Dovey, K. (1999). Framing places: Mediating power in the built form. London, Routledge.

Duncan, N. (1996). Renegotiating gender and sexuality in public and private spaces. Body space. Destabilizing geographies of gender and sexuality. N. Duncan, Ed. London, Routledge: $127-145$.

Fielding, S. (2000). Walk on the left!: Children's geographies and the primary school. In Children's geographies: Playing, living, learning. S. Holloway and G. Valentine, Eds. London, Routledge: $230-244$.

Forty, A. (2000). Words and buildings. A vocabulary of modern architecture. London, Thames \& Hudson.

Foucault, M. (1977). Discipline and punish: The birth of the prison. New York, Vintage Books.

Foucault, M. (1978). The history of sexuality: Volume I: An introduction. New York, Vintage Books.

Foucault, M. (1980). Power/Knowledge: Selected interviews and other writings, 19721977. C. Gordon, Trans. New York, Pantheon Books.

Foucault, M. (1997). Space, knowledge, power. In Rethinking architecture. A reader in cultural theory. N. Leach, Ed. Routledge, London: 367-380.

(Second Author). (2006). Inscribing healthification: governance, risk, surveillance and the subjects and spaces of fitness and health. Journal of Health and Place. 


\section{An ethnographic inquiry into the neo-liberal tactics of social (re)production}

(First Author and Lortie, P (2005). “How does knowin' my business make you any safer?": Critical Pedagogy in Dangerous Times. The Review of Education, Pedagogy, and Cultural Studies.Volume Volume 27(2): 141-158.

Grosz, E. (1995). Space, time and perversion. New York, Routledge.

Grosz, E. (2001). Architecture from the outside. Essays on virtual and real space. Cambridge, MA, MIT Press.

Hollier, D. (1992). Against architecture. The writings of George Bataille. Cambridge, MA, MIT Press.

Holt, L. (2003). (Dis)abling children in primary school micro-spaces: geographies of inclusion and exclusion. Health \& Place, 9: 119-128.

Ingraham, C. (1992). Initial properties: Architecture and the space of the line. Sexuality \& space. B. Colomina, Ed. New York, Princeton Papers on Architecture, Princeton Architectural Press: $255-271$.

Kilian, T. (1998). Public and private, power and space. In The production of public space. A. Light and J. Smith, Eds. Lanham, MD, Rowman \& Littlefield Publishers, Inc.

Lahiji, N. and D. Friedman, Eds. (1997). Plumbing. Sounding modern architecture. New York, Princeton Architectural Press.

Lefebvre, H. (1991). The production of space. Oxford, Blackwell.

Lesko, N. (2001) Act your Age!: A cultural construction of adolescence. New York and London, Routledge Falmer.

Lupton, D. (1999). Risk. London, Routledge.

Markus, T. (1993). Buildings and power. Freedom and control in the origin of modern building types. London, Routledge. 


\section{An ethnographic inquiry into the neo-liberal tactics of social (re)production}

Massey, D. (2000). Space, place and gender. Gender space architecture: An

interdisciplinary introduction. J. Rendell, B. Penner and I. Borden, Eds. London, Routledge: 128133.

Mitchell, D. (1995). “The end of public space? People's Park, definitions of public and democracy." Annales Association of American Geographies 85: 108-133.

Mohanram, M. (1999). Black body: Women, colonialism, and space. Minneapolis, MN, University of Minnesota Press.

Nalbantoglu, G. and C. Wong, Eds. (1997). Postcolonial space(s). New York, Princeton Architectural Press.

Nast, H. and S. Pile, Eds. (1998). Places through the body. New York, Routledge.

New York Times. (2004). Saturday, January 17, B4.

O’ Malley, P. (1996). Risk and responsibility. Foucault and political reason: Liberalism, neo-liberalism and rationalities of government. A. Barry, T. Osborne \& N. Rose, Eds, London, UCL Press: 189-207.

Philo, C. (2004). Michel Foucault. Key thinkers on space and place. P. Hubbard, R. Kitchin \& G. Valentine, Eds. London, Sage: 121-128.

Pile, S. and M. Keith, Eds. (1997). Geographies of resistance. London, Routledge. Razack, S. (1998). "Race, space and prostitution.” Canadian Journal of Women and the Law 19(2): 338-376.

Razack, S. (1999). "Making Canada White: Law and the policing of bodies in the 1990's." Canadian Journal of Law and Society 14(1): 159-184.

Razack, S. (2000a). "From the "clean snows of Petawawa": The violence of Canadian Peacekeepers in Somalia.” Cultural Anthropology 15(1): 127-163. 


\section{An ethnographic inquiry into the neo-liberal tactics of social (re)production}

Razack, S. (2000b). “Gendered racial violence and spatialized justice: The murder of Pamela George." Canadian Journal of Law \& Society 15(2).

Rendell, J. (1998). "West End rambling: Gender architectural space in London 1800-1830." Leisure Studies 17(2): 108-122.

Rendell, J., Penner, B., and I. Borden. Eds. (2000). Gender, space, architecture. London, Routledge.

Rose, N. (1996). Inventing ourselves: Psychology, power, and personhood. London, Cambridge University Press.

Ruddick, S. (1990). "Heterotopias of the homeless: Strategies and tactics of placemaking in Los Angeles.” Strategies 3: 184-201.

Ruddick, S. (1997). “Constructing difference in public space: Race, class and gender as interlocking systems.” Urban Geography 17: 131-151.

Scruton, R. (1979). The aesthetics of architecture. Princeton, NJ, Princeton University Press.

Shields, R. (2004). Henri Lefebvre. Key thinkers on space and place. P. Hubbard, R. Kitchin \& G. Valentine, Eds. London, Sage: 208-213.

Sibley, D. (1995). Geographies of exclusion. London, Routledge.

Skelton, T, and G. Valentine (Eds.). (1998). Cool places: Geographies of youth culture. London, Routledge.

Valentine, G. (1996). (Re)negotiating the 'heterosexual street.' Lesbian productions of space. Body space. Destabilizing geographies of gender and sexuality. N. Duncan, Ed. London, Routledge: 146-153. 


\section{An ethnographic inquiry into the neo-liberal tactics of social (re)production}

Valentine, G. (1997). (Hetero)sexing space: Lesbian perceptions and experiences of

everyday spaces. Space, gender and knowledge. L. McDowell and J. Sharpe, Eds. London,

Arnold: 284-300.

Valentine, G. (2000). Exploring children and young people's narratives of identity.

Geoforum, 31: 257-267.

Virilo, P. (1997). The overexposed city. In Rethinking architecture. A reader in cultural

theory. N. Leach, Ed. London, Routledge: 381-390.

Whiteman, J., Kipnis, J. and R. Burdett, Eds. (1992). Strategies in architectural thinking.

Cambridge, MA, MIT Press.

Wigley, M. (1992). Untitled: The housing of gender. Sexuality \& space. B. Colomina, Ed.

New York, Princeton Papers on Architecture, Princeton Architectural Press: 327-389.

Wilson, M. (1998). Dancing in the dark: The inscription of Blackness in Le Corbusier's

Radiant city. Places through the body. H. Nast and S. Pile, Eds. London, Routledge: 133-152.

Yon, D. (2000). Elusive culture: schooling, race, and identity in global times. New York,

State University of New York Press.

\footnotetext{
${ }^{\mathrm{v}}$ See (second author) 2006 Inscribing healthification: governance, risk, surveillance and the subjects and spaces of fitness and health. Journal of Health and Place.

ii The empirical data used in this paper come from 's (first author) study, Drama Education, Youth, and Social Cohesion: (Re)Constructing Identities in Urban Contexts. Gratitude to the Social

${ }^{\text {ii }}$ The empirical data used in this paper come from 's (first author) study, Drama Education, Youth, and Social Cohesion: (Re)Constructing Identities in Urban Contexts. Gratitude to the Social Sciences and Humanities Research Council of Canada for their generous support.

${ }^{\text {iii }}$ With strong bipartisan support President Bush created the Department of Homeland Security - the most comprehensive reorganization of the Federal government in a half-century. The Department of Homeland Security consolidates 22 agencies and 180,000 employees, unifying once-fragmented Federal functions in a
} 


\section{I.D.ology and the Technologies of Public (School) Space: An ethnographic inquiry into the neo-liberal tactics of social (re)production}

single agency dedicated to protecting America from terrorism. Retrieved from:

http://www.whitehouse.gov/homeland

iv The creation of Public Safety and Emergency Preparedness Canada (PSEPC) fulfills the fundamental role of government to secure the public's safety and security. PSEPC is dedicated to minimizing a continuum of risks to Canadians -- from risks to personal safety from crime or naturally occurring events such as severe blizzards, floods or forest fires, to threats to national security from terrorist activity. Retrieved from: http://www.ocipep.gc.ca/

${ }^{\mathrm{V}}$ In the USA, following a three-year partnership (Safe School Initiative) between the Department of Education and the Secret Service, two reports were published that detail the study's findings and lay out a process for threat assessment in schools; Implications for Prevention of School Attacks in the United States; A Guide to Managing Threatening Situations and to Creating Safe School Climates. Retrieved from: http://www.secretservice.gov/ntac ssi.shtml

In Canada, education is under provincial jurisdiction. The Ontario Safe Schools Act Bill 81 (2000) is an act to increase respect and responsibility, to set standards for safe learning and safe teaching in schools.

Retrieved from: http:/www.edu.gov.on.ca/safeschl/eng/ssa.html

${ }^{\text {vi }}$ For a further analysis of this vital conversation among students in one Toronto public school, see__ 's (first author) and Lortie (2005) "How does knowin' my business make you any safer?": Critical Pedagogy in Dangerous Times. The Review of Education, Pedagogy, and Cultural Studies.Volume Volume 27(2): 141-158. 